\title{
Pengembangan Perangkat Pembelajaran Pada Materi Usaha dan Energi Berbasis Project Based Learning
}

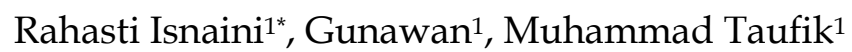 \\ 1Pendidikan Fisika, FKIP, Universitas Mataram, Lombok, Indonesia.
}

DOI: $10.29303 /$ goescienceedu.v2i2.128

\section{Article Info}

Received: 28 juli 2021

Revised: 15 Desember 2021

Accepted: 27 Desember 2021

\begin{abstract}
Abstrak: Penelitian ini bertujuan untuk mengembangkan perangkat pembelajaran pada materi usaha dan energi berbasis model project based learning yang layak digunakan dalam pembelajaran. Penelitian ini merupakan penelitian pengembangan (research and development) dengan desain model pengembangan 4D yang terdiri atas 4 tahapan yaitu: define (pendefinisian); design (perancangan); develop (pengembangan); dan disseminate (penyebaran). Penelitian ini hanya sampai tahap develop (pengembangan). Berdasarkan hasil validasi oleh ahli, pengembangan perangkat pembelajaran dalam penelitian ini valid. Persentase validitasnya sebesar $87,5 \%$ pada silabus; $87,5 \%$ pada rencana pelaksanaan pembelajaran; dan $82,5 \%$ pada lembar kerja peserta didik. Berdasarkan hasil tersebut, pengembangan perangkat pembelajaran dalam penelitian ini layak digunakan dengan revisi pada bagian lembar kerja peserta didik karena memiliki kriteria cukup valid.

Kata Kunci: Perangkat Pembelajaran; Model Project Based Learning.
\end{abstract}

Abstract: This study aimed to develop learning tools on business and energy materials based on project based learning models that are suitable for use in learning. This research was a development research by 4Ddevelopment model design consisting of 4 stages, namely: define; design, develop, and disseminate. This research was only up to the stage of development. Based on the results of validation by experts, the development of learning tools in this study was valid. The percentage of validity was $87.5 \%$ on the syllabus; $87.5 \%$ on the lesson plan implementation; and $82.5 \%$ on student worksheets. Based on the results, the development of learning tools in this study is feasible to use with revisions to the student worksheet because it has quite valid criteria.

Keywords: Learning Devices; Project Based Learning Model.

\section{Pendahuluan}

Kurikulum 2013 mengharuskan guru untuk menyusun perangkat pembelajaran sesuai komponenkomponen yang telah dimuat dalam Permendikbud RI No 103 dan 104 Tahun 2014. Proses pembelajaran kurikulum 2013 dilaksanakan dengan menggunakan pendekatan ilmiah yang menyentuh tiga ranah yaitu sikap, pengetahuan dan keterampilan. Mata pelajaran fisika dikembangkan dengan mengacu pada kemampuan observasi dan eksperimen serta berpikir kritis peserta didik sesuai dengan tujuan kurikulum 2013. Peserta didik menyatakan mata pelajaran fisika merupakan mata pelajaran yang kurang menarik, sulit dipahami, dan sangat membosankan sehingga banyak peserta didik tidak memperhatikan guru ketika pembelajaran berlangsung dan sibuk dengan kegiatan masing-masing.

Perangkat pembelajaran adalah sarana penunjang pembelajaran yang berisi perencanaan pembelajaran yang menguraikan tentang kompetensi yang akan dicapai peserta didik. Menurut Devi (2009) perangkat pembelajaran sebagai pegangan bagi guru dalam melaksanakan pembelajaran baik dikelas, laboratorium, atau lapangan untuk setiap kompetensi dasar. Rancangan pembelajaran harus mengikuti sintak 
model pembelajaran tertentu, sebagai pedoman peserta didik dan alat untuk mengukur ketercapaian kompetensi peserta didik. Perangkat pembelajaran yaitu rancangan pembelajaran yang berisi silabus, RPP dan LKPD sebagai pedoman bagi guru yang digunakan untuk kegiatan pembelajaran baik dikelas, laboratorium dan lingkungan.

Model pembelajaran project based learning merupakan model pembelajaran yang inovatif yang berpusat pada peserta didik dan menempatkan guru sebagai motivator dan fasilitator, peserta didik diberi peluang untuk bekerja secara mandiri. Model project based learning dapat memberikan peserta didik kebebasan dalam berpikir kreatif serta berpartisipasi dalam mengembangkan potensi yang ada pada diri peserta didik. Menurut Doppelt (2005) menyatakan bahwa salah satu metode yang didasarkan pada konstruktivisme yang mendukung keterlibatan peserta didik dalam situasi pemecahan masalah adalah project based learning. Model pembelajaran project based learning adalah model pembelajaran yang berpusat pada peserta didik untuk mengembangkan sikap ilmiah seperti menganalisis fenomena-fenomena alam dan menghasilkan karya nyata sehingga dapat memberikan pemahaman terhadap fenomena-fenomena tersebut.

Langkah-langkah model pembelajaran project based learning terdapat 6 tahapan diantaranya sebagai berikut: 1) pertanyaan dasar (start with essensial question), guru harus mampu mengambil topik yang sesuai dengan realitas dunia nyata untuk mengawali investigasi; 2) perencanaan proyek (plan design project), peserta didik membuat perencanaan dan gambar proyek yang akan dibuat; 3) menyusun jadwal aktivitas (create schedule) peserta didik membuat dan mengatur jadwal yang akan dilakukan selama proses pembelajaran; 4) memonitor aktivitas peserta didik (monitoring the students and progress of project) guru mengawasi kegiatan peserta didik selama menyelesaikan proyek; 5) penilaian (assess the outcome) guru memberikan penilaian terhadap hasil proyek yang telah dibuat; 6) evaluasi (evaluate the experience) guru memberikan pemahaman-pemahaman tambahan terhadap proyek yang telah dibuat dan memberikan kesempatan kepada peserta didik untuk mengungkapkan pendapat terhadap proses pembelajaran.

\section{Metode}

Penelitian ini menggunakan jenis penelitian Research and Development. Menurut Haryati (2012) penelitian Research and Development adalah metode penelitian yang digunakan untuk menghasilkan produk tertentu dan menguji keefektifan produk tersebut. Penelitian yang dikembangkan yaitu perangkat pembelajaran berbasis project based learning pada materi usaha dan energi yang valid sehingga dapat dimanfaatkan dalam dunia pendidikan. Perangkat yang dikembangkan yaitu silabus, rencana pelaksanaan pembelajaran (RPP) dan lembar kerja peserta didik (LKPD). Desain penelitian yang digunakan adalah model 4D yaitu tahap pendefinisian (define), tahap perancangan (design), tahap pengembangan (develop) dan tahap penyebaran (disseminate). Pengembangan dalam penelitian ini digunakan hingga tahap pengembangan (develop) saja.

a) Tahap define (pendefinisian) dilakukan analisis. Adapun tujuan dari tahapan ini adalah menetapkan dan mendefinisikan syarat pembelajaran yang diawali dengan analisis tujuan dan kebutuhan.

b) Tahap design (perancangan) awal perangkat pembelajaran dilakukan penyusunan draft awal yang akan menghasilkan draft silabus, RPP, dan LKPD untuk pembelajaran dengan model project based learning yang kemudian akan dinilai melalui lembar validasi ahli oleh validator.

c) Tahap develop (pengembangan) merupakan tahapan realisasi dari rancangan produk perangkat pembelajaran yang akan digunakan. Tahap ini, bertujuan untuk menghasilkan dan memvalidasi perangkat pembelajaran yaitu Silabus, RPP, LKPD.

Instrumen penelitian yang digunakan adalah angket validasi sebagai instrumen pengumpulan data. Instrumen ini dibutuhkan sebagai alat untuk mengukur kelayakan perangkat pembelajaran yang dikembangkan. Instrumen pengumpulan data yang digunakan dalam penelitian ini adalah lembar validasi yang digunakan untuk mendapatkan data penilaian perangkat pembelajaran oleh validator, serta mendapatkan saran untuk memperbaiki perangkat pembelajaran yang sudah dikembangkan.

Data penelitian dikumpulkan dengan menggunakan lembar validasi ahli. Analisis data menggunakan skala likert. Rumus untuk menghitung persentase sebagai berikut:

Keterangan:

$$
P=\frac{f}{N} \times 100 \%
$$

$f=$ Skor yang didapat

$N$ = Jumlah Frekuensi/skor maksimal

$\mathrm{P}=$ Angka Persentase

Skala yang digunakan dalam penelitian ini adalah ratting scale dengan 4 pilihan sesuai dengan konten pertanyaan pada angket. Pengubahan hasil dari kata sifat menjadi angka sebagai berikut: 
Tabel 1 Skor Penilaian Terhadap Pilihan Jawaban

\begin{tabular}{ll}
\hline Pilihan Jawaban & Skor \\
\hline Baik & 4 \\
Kurang baik & 3 \\
Cukup baik & 2 \\
Tidak baik & 1 \\
\hline
\end{tabular}

Angket validasi dan respon menggunakan 4 pilihan sesuai dengan konten pertanyaan. Data presentase yang diperoleh selanjutnya dikonversi menjadi kriteria validitas perangkat pembelajaran yang tercantum pada Tabel 2 berikut.

Tabel 2 Kriteria Validitas Perangkat Pembelajaran

\begin{tabular}{ll}
\hline Presentase & Skor \\
\hline $85,1 \%-100 \%$ & Valid \\
$70,1 \%-85 \%$ & Cukup valid \\
$50,1 \%-70 \%$ & Kurang valid \\
$0 \%-50 \%$ & Tidak Valid \\
\hline
\end{tabular}

\section{Hasil dan Pembahasan}

Pada tahap define (pendefinisian) dilakukan beberapa analisis yaitu analisis awal, analisis peserta didik, analisis tugas dan analisis konsep. Hasil analisis di madrasah mengidentifikasikan bahwa dibutuhkan perangkat pembelajaran (silabus, RPP dan LKPD) yang dapat memberikan pengalaman dan meningkatkan pemahaman serta keaktifan bagi peserta didik. Perangkat pembelajaran berbasis proyek belum pernah diterapkan di madrasah sehingga akan menjadi pengalaman baru bagi peserta didik, maka dikembangkanlah perangkat pembelajaran fisika berbasis project based learning pada materi usaha dan energi. Pada tahap design (perancangan) dihasilkan suatu draft perangkat pembelajaran (silabus, RPP dan LKPD) berbasis model project based learning. Materi yang dipilih adalah materi usaha dan energi berdasarkan kurikulum 2013.

Langkah selanjutnya dilakukan validasi perangkat oleh 3 validator ahli terdiri dari 3 dosen fisika. Hasil dari penilaian validator ahli berupa skor kuantitatif. Aspek yang dinilai yaitu silabus, RPP dan LKPD. Penilaian dari validator ahli untuk keseluruhan perangkat sebesar $85,8 \%$ sehingga memperoleh kategori valid dan layak digunakan. Dapat disimpulkan bahwa perangkat pembelajaran pada materi usaha dan energi berbasis model project based learning mendapatkan kategori valid dan layak digunakan.

\section{Kesimpulan}

Berdasarkan hasil penelitian dan pembahasan, maka diperoleh kesimpulan bahwa pengembangan perangkat pembelajaran berbasis project based learning layak digunakan, tetapi membutuhkan sedikit revisi

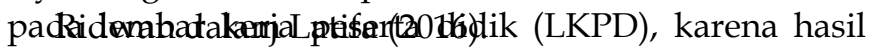
validitas produk penelitian memiliki kriteria cukup valid. Persentase keseluruhan hasil validasi menunjukkan bahwa perangkat pembelajaran fisika berbasis project based learning pada materi usaha dan energi yang dirancang valid dan layak digunakan. Nilai rata-rata persentase hasil validasi yang belum mencapai hasil maksimal yaitu $100 \%$ disebabkan kurangnya isi materi yang disampaikan, penulisan nomor yang belum teratur, dan penggunaan bahasa yang digunakan.

\section{Daftar Pustaka}

Devi, P. K., Sofiraeni, R., \& Khairuddin, K. (2009). Pengembangan perangkat pembelajaran untuk guru SMP. Pusat Pengembangan Dan Pemberdayaan Pendidik Dan Tenaga Kependidikan Ilmu Pengetahuan Alam, 69. Retrieved from: https://mgmpmatsatapmalang.files.wordpress.c om/2012/07/pengembanganperangkatsmp.pdf

Doppelt, Y. (2005). Assessment of project-based learning in a Mechatronics context. Journal of Technology Education, 16(2), 7-24. https://doi.org/10.21061/jte.v16i2.a.1

Haryati, S., (2012). Research and Development (R\&D) sebagai salah satu model penelitian dalam bidang pendidikan. Majalah Ilmiah Dinamika, 37(1), p.15.

Kanginan, M. (2013). Fisika Untuk SMA/MA Kelas XI. Jakarta: Erlangga.

Kurniaman, O. and Noviana, E., (2017). Penerapan Kurikulum 2013 dalam meningkatkan keterampilan, sikap, dan pengetahuan. Primary: Jurnal Pendidikan Guru Sekolah Dasar, 6(2). 389396.

Rahayu, N. M. S., Sadia, I. W., \& Pujani, N. M. (2018). Pengembangan Perangkat Pembelajaran Fisika SMK dengan Setting Project Based Learning ( PjBL ) untuk Mengembangkan Soft Skill Siswa. Jurnal Pendidikan Dan Pembelajaran IPA Indonesia, $8(2), 81-89$.

Sahidu, C. (2017). Program Pembelajaran Fisika (P3F). Mataram:Arga Puji Press.

Setyosari, P. (2013). Metode Penelitian Pendidikan dan Pengembangan. Jakarta: Kencana Prenada media Group. 
Siwa, I. B., Muderawan, I W., \& Tika, I N. (2013). Pengaruh pembelajaran berbasis proyek dalam pembelajaran kimia terhadap keterampilan proses sains ditinjau dari gaya kognitif siswa. EJournal Program Pascasarjana Universitas Pendidikan Ganesha, 3(1): 1-13.

Sudewi, N L., Suharsono, \& Kirna. (2013). Penerapan model pembelajaran berbasis proyek untuk meningkatkan kemampuan berfikir kritis pada siswa kelas $\mathrm{X}$ multimedia 3 SMK negeri 1 sukasada. e-journal program pascasarjana universitas pendidikan ganesha prodi teknologi pembelajaran. 3(1): 1-11.

Suranti, N. M. Y., Gunawan, G., \& Sahidu, H. (2017). Pengaruh Model Project Based Learning Berbantuan Media Virtual Terhadap Penguasaan Konsep Peserta didik pada Materi Alat-alat Optik. Jurnal Pendidikan Fisika Dan Teknologi, 2(2), 73. https://doi.org/10.29303/jpft.v2i2.292 